\title{
Speciation of Chromium in Bottom Ash Obtained by the Incineration of the Leather Waste Shavings
}

\author{
K. Louhab and H. Akssas \\ Laboratory of Environment and Waste Management, Environment Department \\ Faculty of Engineer Sciences, University of Boumerdes, 35000-Boumerdes, Algeria
}

\begin{abstract}
The evolution of bottom ash morphology and chromium metals behavior during incineration of a leather waste shavings at different incineration temperature have been studied. $\mathrm{The} \mathrm{Cr}, \mathrm{Ca}, \mathrm{Mg}, \mathrm{Cl}$ rates in bottom ashes, flay ashes and emitted gases in different incineration temperature of the tannery wastes are also determined. The morphology of the bottom ashes obtained by incineration at different temperature from the leather waste shavings was examined by MEB. The result show that the temperature and the length of incineration influence on the structure of the bottom ash and on the chromium in the bottom ash.
\end{abstract}

Key words: Chromium, incineration, bottom ash, characterization, leather waste shaving

\section{INTRODUCTION}

Historically, shavings, trimmings and splits from the chrome tanning of hides and skins have been disposed of in landfills. Increased local restrictions on land disposal have encouraged the tanning industry to explore more methods to treat this waste product, include air oxidation ${ }^{[1]}$, peroxide treatments ${ }^{[2]}$. Chromium with the $(+6)$ oxidation state would be generated in these reactions and a reduction step would be needed.

Accordingly, considerable attention has been focused in recent years for used the incineration of waste $^{[3-6]}$ such as leather Solid Waste incineration is a spreading technique because of two main points:

* It reduces the volume and mass of the waste while simultaneously generating power. The treatment of the solid and gaseous effluents containing chromium metals is an important environmental and economical issue since the release of toxic metals is strictly controlled and the regulation may become even stricter in the future.

* Metals in wastes are introduced into combustion chambers in many physical and chemical forms. Nevertheless, during incineration, Heavy Metals (HM) are only transformed and concentrated in the various final residues (Bottom ash, Filter ash and residues from the Air Pollution Control Devices) and in gaseous emissions, which represent potential sources of pollution.

A problem observed by this method was:

* The chromium species as a function of temperature and chlorine concentration in the flue gas. A small fraction of the hexavalent $\mathrm{CrO}_{3}$ is formed at high temperatures under all chlorine conditions.
However, different auteur ${ }^{[7-9]}$ suggests that high chlorine levels might promote the formation of the carcinogenic hexavalent $\mathrm{CrO}_{2} \mathrm{Cl}_{2}$ in a temperature window around $700 \mathrm{~K}$.

* Leaching of chromium from the bottom ash obtained is considered as main problems in uncontrolled disposal sites ${ }^{[10,11]}$, or in its recycling as raw material for ordinary Portland cement and construction material such as aggregate.

\section{MATERIALS AND METHODS}

Incineration of the leather waste shavings: The tests of incineration of waste of the tannery are carried out in a horizontal incinerator of static type, it consists of an internally papered metal envelope refractory bricks thickness of 100 Misters This incinerator comprises a combustion chamber equipped with a burner and a ventilator which it contribution of the primary air for combustion and a room of post -combustion equipped with a burner and a ventilator ensuring the secondary air of the room of post - combustion; it is prolonged by an intended vertical room to complete the combustion of gases, followed by a stack for evacuation. The temperature of combustion is adjusted with the assistance of an electronic equipment allowing to program temperature which makes it possible to vary the temperature of combustion between 700 to $1400{ }^{\circ} \mathrm{C}$.

The leather waste shavings are introduced into the furnace (combustion chamber) continuously using a stainless cane, cooled by water. They are injected by pneumatic way, through air compression with a flow of approximately $6 \mathrm{Nm}^{3} \mathrm{~h}^{-1}$. The flow of waste is adjusted at the time of each of incineration so as to maintain constant the temperature of combustion.

Corresponding Author: $\quad$ K. Louhab, Laboratory of Environment and Waste Management, Environment Department. Faculty of Engineer Sciences, University of Boumerdes, 35000 - Boumerdes - Algeria, Tel/Fax: 213-24 818270 
Table 1: Analyses of the leather waste shavings

\begin{tabular}{lc}
\hline Parameter & Percentage \\
\hline Moisture & 53.51 \\
Ash & 14.32 \\
Chromic oxide & 4.21 \\
TNK & 14.54 \\
Fat & 0.09 \\
Calcium & 0.34 \\
Magnesium & 0.33 \\
Chloride & 0.42 \\
\hline
\end{tabular}

The bottom ashes, defined as being the residues of combustion remaining in the hot zone, are recuperated by the opening of a trap door situated at the end of the combustion chamber.

The bottom ashes were collected in the incinerator and were air dried in incubation oven at $100^{\circ} \mathrm{C}$ to a constant mass. They were cooled to a room temperature in a decicator. They were homogenized in large tube by gently mixing. After mixing, they were transferred to high density polyethylene bags, sealed and stored at $4{ }^{\circ} \mathrm{C}$

Electron microscopy studies: The effect of treatment on the characteristics of the bottom ash obtained at different incineration temperature from the leather waste shavings, a balayage electron microscope JEOL 200 CX (B.E.M) was used.

Leather waste shavings composition: The leather waste shaving sample was obtained from tannery factory in Rouiba (TAMEG), Algeria, using goatskin raw material, is representative of tannery seedlings in Algeria. The amount of leather waste shaving generated is 20 tons (dry weight) monthly.

The leather waste shavings were analyzed for moisture; ash, chromic oxide, total ash, Total Kjeldhal Nitrogen (NTK), calcium, magnesium and chromium have been described in Taylor et al. ${ }^{[14]}$ works. Table 1 shows the results of these analyses.

Bottom ash composition at different incineration temperature: In order to analyse total metal chromium content in the bottom ash, $50 \mathrm{~g}$ of bottom ash was put into a $500 \mathrm{~cm}^{3}$ Pyrex flask. $100 \mathrm{~cm}^{3}$ of aqua regia $(4 \mathrm{~N}$ $\left.\mathrm{HNO}_{3}-4 \mathrm{~N} \mathrm{H}_{2} \mathrm{SO}_{4}\right)^{[12]}$ was added to the bottom ash and then placed on a heating plate. The suspension was cooled and filtered through a $0.45 \mu \mathrm{m}$ membrane filter and the chromium content in the filtrate was measured by atomic absorption spectroscopy (Perkin Elmer 2380). The determination of $\mathrm{Cr}(\mathrm{VI})$ was by the sbiphenyl carbazide method ${ }^{[13]}$. The bottom ashes were analyzed for calcium, magnesium and chloride at different incineration temperature by the method described in the works of Taylor ${ }^{[14]}$.

The qualitative analysis of the bottom ash obtained after one hours and two hours of incineration at $950^{\circ} \mathrm{C}$ from the leather waste shavings by X-ray diffraction (XRD, $X^{\prime}$ pert) was carried out using a PHILIPS PW
1404 with a vacuum Rhodium anode of $3 \mathrm{~Pa}$, the spectrum of X-ray diffraction of the element to be analyzed is traced according to angle 2 theta.

\section{RESULTS AND DISCUSSION}

Effect of the temperature of incineration on morphology of the bottom ashes: On the Fig. 1A-C are presented respectively the bottom ashes obtained by incineration at different temperature from the leather waste shavings.
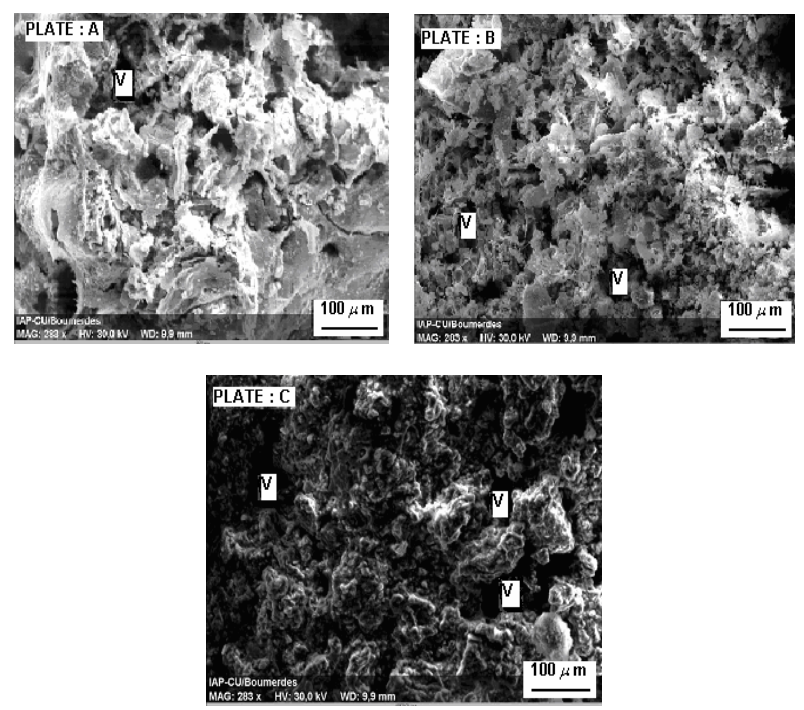

Fig. 1: Electron Micrographs of the bottom ashes obtained by incineration at different temperature from the leather waste shavings $(\mathrm{V}=$ bladders $)$

PLATE A: Incineration temperature $=850^{\circ} \mathrm{C}$

PLATE B: Incineration temperature $=950^{\circ} \mathrm{C}$

PLATE C: Incineration temperature $=1050^{\circ} \mathrm{C}$

The photographs of bottom ash obtained by microscopy electronic put in evidence a granular material resembling of the slags. It is about porous particles with bladders. It implies important specific surfaces therefore for the granular material. This important specific surface implies an important reaction surface therefore at the time of the different tests of extractions of the chromium by the different solvents. The porous particle apparition with bladders become more pronounced with the increase of the incineration temperature $^{[15]}$.

Effect of the temperature of incineration on the composition of the bottom ash: In Fig. 2 is reported simultaneously the quantity of Chromium, Calcium, Chloride, Magnisium in the bottom ash and in the flyashes and it in the gas phase obtained at different incineration temperature (the quantity of Chromium, Calcium, Chloride, Magnesium in the fly-ashes and the gas phase is deducted by the difference between the 
Am. J. Environ. Sci. 2 (3): 79-83, 2006

Table 2: Chromium determination in the bottom ash obtained by incinerated with different temperatures

\begin{tabular}{|c|c|c|c|c|c|}
\hline Incineration temperature ${ }^{\circ} \mathrm{C}$ & $\mathrm{Q}(\mathrm{mg} / \mathrm{g})(\mathrm{a})$ & $\mathrm{Cr}(\mathrm{VI})(\mathrm{mg} / \mathrm{g})(\mathrm{b})$ & $\% \mathrm{Cr}(\mathrm{VI})(\mathrm{c})$ & $\mathrm{Cr}(\mathrm{III})(\mathrm{mg} / \mathrm{g})(\mathrm{d})$ & $\% \mathrm{Cr}(\mathrm{III})(\mathrm{e})$ \\
\hline 850 & 170 & 52.7 & 31 & 117.3 & 69 \\
\hline 950 & 182 & 5.09 & 28 & 131 & 72 \\
\hline 1050 & 200 & 44 & 22 & 156 & 78 \\
\hline 1150 & 213.5 & 42.6 & 19.9 & 188.9 & 81.5 \\
\hline \multicolumn{6}{|c|}{$\begin{array}{ll}\text { a } & \text { Chromium quantity in a gram of bottom ash }\end{array}$} \\
\hline \multicolumn{6}{|c|}{ b Quantity of $\mathrm{Cr}(\mathrm{VI})$ in a gram of bottom ash } \\
\hline \multirow{2}{*}{\multicolumn{6}{|c|}{$\mathrm{Cr}(\mathrm{VI})$ rate in accordance to $\mathrm{Cr}(\mathrm{VI})$ quantity existing in the bottom ash }} \\
\hline \multicolumn{2}{|c|}{ d Quantity of $\mathrm{Cr}$ (III) in a gram of bottom ash } & & & & \\
\hline \multicolumn{6}{|c|}{$\mathrm{e} \quad \mathrm{Cr}$ (III) rate in accordance to $\mathrm{Cr}$ (III) quantity existing in the bottom ash } \\
\hline \multicolumn{6}{|c|}{ Table 3: Sequential extraction procedures } \\
\hline Fraction & \multicolumn{3}{|c|}{ Extractant } & \multicolumn{2}{|c|}{ Extraction condition } \\
\hline Exchangeable & \multicolumn{3}{|c|}{$10 \mathrm{ml} 1 \mathrm{M} \mathrm{MgCl}_{2}$} & \multicolumn{2}{|c|}{ Shaken $1 \mathrm{~h}$ at $\mathrm{pH} 7$} \\
\hline Carbonates-bound & \multicolumn{3}{|c|}{$10 \mathrm{ml} 1 \mathrm{M} \mathrm{NaAc}$} & \multicolumn{2}{|c|}{ Shaken $5 \mathrm{~h}$ at $\mathrm{pH} 5$} \\
\hline Oxides-bound & \multicolumn{3}{|c|}{$20 \mathrm{ml} 0.04 \mathrm{M} \mathrm{NH}_{2} \mathrm{OH} . \mathrm{HCl}$} & \multicolumn{2}{|c|}{ Shaken $5 \mathrm{~h}$ at $85^{\circ} \mathrm{C}$} \\
\hline \multirow{2}{*}{$\begin{array}{l}\text { Organic-bound } \\
\text { Residual }\end{array}$} & \multicolumn{3}{|c|}{$20 \mathrm{ML} 30 \% \mathrm{H}_{2} \mathrm{O}_{2}$ and $10 \mathrm{ml}$ conc. $\mathrm{H}_{2} \mathrm{SO}_{4}$} & \multirow{2}{*}{\multicolumn{2}{|c|}{$\begin{array}{l}\text { Shaken } 2 \mathrm{~h} \text { and } 3 \mathrm{~h} \text {, respectively, at } 85^{\circ} \mathrm{C} \\
\text { Mildly boiled for } 1 \mathrm{~h}\end{array}$}} \\
\hline & & c. $\mathrm{H}_{2} \mathrm{SO}_{4}$ & & & \\
\hline
\end{tabular}

Table 4: Fractions of $\mathrm{Cr}$ in Bottom ash obtained after incineration at different temperature

\begin{tabular}{llcc}
\hline Incineration temperature ${ }^{\circ} \mathrm{C}$ & & Concentration $(\mathrm{mg} / \mathrm{g})$ & Percentage \\
\hline \multirow{4}{*}{850} & Exchangeable & 42.50 & 25.00 \\
& Carbonates-bound & 18.53 & 10.90 \\
& Oxides-bound & 30.77 & 18.10 \\
& Organic-bound & 50.66 & 29.80 \\
& Residual & 24.14 & 14.20 \\
\hline \multirow{4}{*}{950} & Exchangeable & 42.20 & 23.20 \\
& Carbonates-bound & 30.75 & 16.90 \\
& Oxides-bound & 35.85 & 19.70 \\
& Organic-bound & 49.68 & 27.30 \\
1050 & Residual & 23.47 & 12.90 \\
& Exchangeable & 40.20 & 20.10 \\
& Carbonates-bound & 44.20 & 22.70 \\
& Oxides-bound & 40.40 & 20.20 \\
& Organic-bound & 50.00 & 25.00 \\
& Residual & 24.00 & 12.00 \\
\hline \multirow{4}{*}{1150} & Exchangeable & 39.29 & 18.44 \\
& Carbonates-bound & 53.73 & 25.20 \\
& Oxides-bound & 50.22 & 21.50 \\
\end{tabular}

quantity of Chromium, Calcium, Chloride, Magnesium, in the leather waste shavings and the quantity of Chromium, Calcium, Chloride, Magnesium in the bottom ash.

According to the results, the chromium is found in fly ash and produced gas for a temperature of incineration of $850{ }^{\circ} \mathrm{C}$, but rather in the bottom ash at temperature of incineration of $1150^{\circ} \mathrm{C}$. This phenomenon is due probably on our opinion to the existence of chlorine in the leather waste shavings which supports the appearance of metallic chlorures ${ }^{[9]}$ and according to authors ${ }^{[7,8]}$ the chromium in a low temperature ranging around $850^{\circ} \mathrm{C}$ has, within which $\mathrm{CrO}_{2} \mathrm{Cl}_{2}$ (gas) is thermodynamically predicted to appear such as the chlorine will enhance the vaporization of metals at low temperature.

Chromium determination in the bottom ash obtained by incinerated with different temperatures: The speciation of chromium compounds is extremely important. Hexavalent chromium $\left(\mathrm{Cr}^{+6}\right)$ is considered a potent carcinogen at low concentration, while trivalent chromium $\left(\mathrm{Cr}^{+3}\right)$ has a hogher toxicity threshold. Table 2 shows the quantity of total $\mathrm{Cr}$ and $\mathrm{Cr}(\mathrm{VI})$ content in the bottom ash obtained by incineration at different temperature from the leather waste shavings.

Figure 3 shows XRD patterns of the bottom ash obtained after 1 and 2 hours of incineration at $950^{\circ} \mathrm{C}$. After one hours $(1 \mathrm{~h})$ of incineration, the peak of Chromium oxide $\left(\mathrm{Cr}_{2} \mathrm{O}_{3}\right)$ was obseved. The peak of Chromium oxide $\left(\mathrm{Cr}_{2} \mathrm{O}_{3}\right)$ decreased and the peak of Sodium Chromium Oxide $\left(\mathrm{Na}_{2} \mathrm{CrO}_{4}\right)$ appeared with increased the length of incineration (after two hours of incineration à $950^{\circ} \mathrm{C}$ ). This result implies that a part of trivalent chromium $\left(\mathrm{Cr}^{+3}\right)$ changes in hexavalent chrome $\left(\mathrm{Cr}^{+6}\right)$ under shape of $\mathrm{Na}_{2} \mathrm{CrO}_{4}$ when one increases the time of incineration

In the $\mathrm{Cr}$ fractionation experiment in the bottom ash obtained by incineration at different temperature 

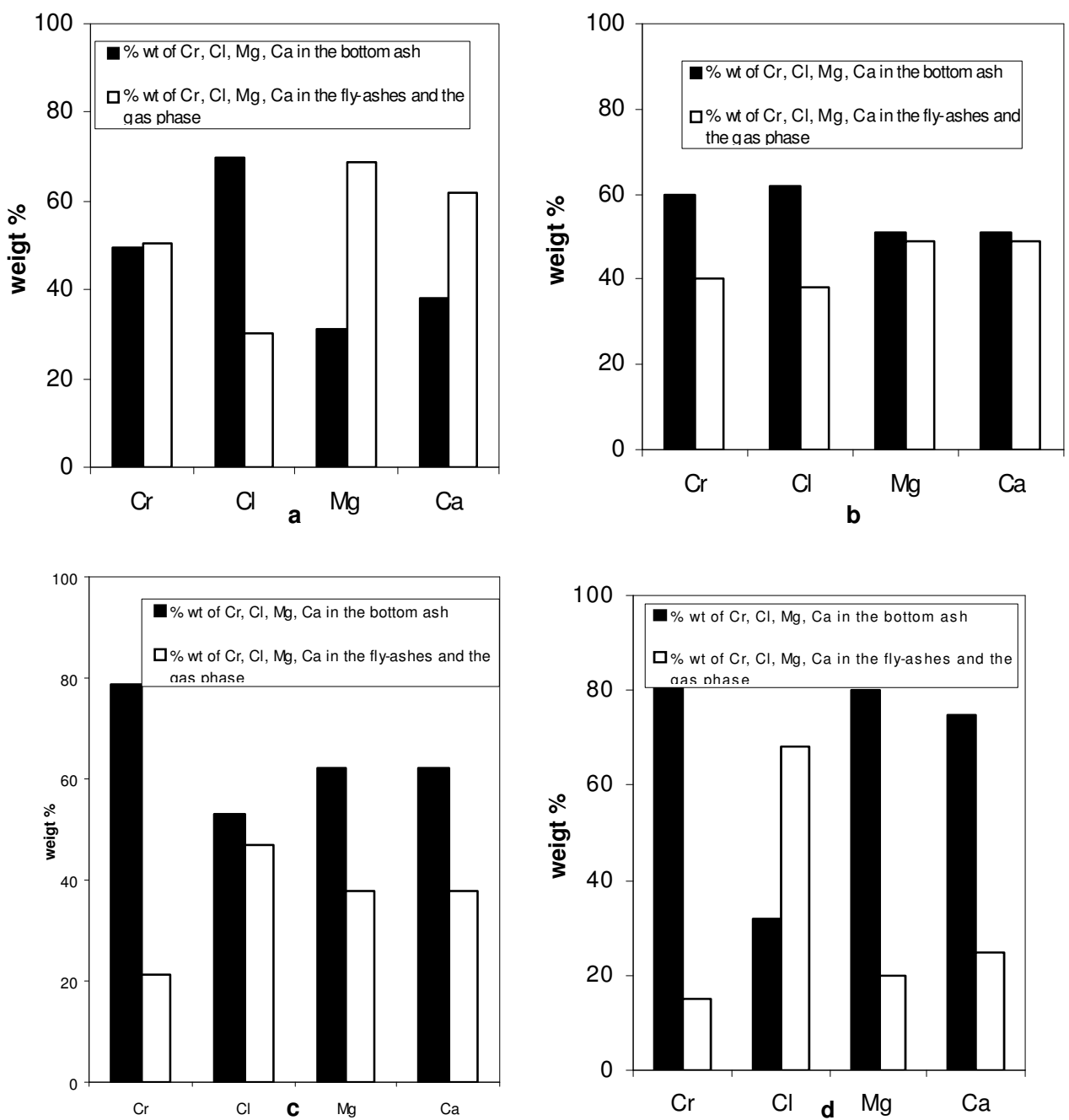

Fig. 2: Chromium, Calcium, Chloride, Sodium rate in bottom ashes, flay ashes and emitted gas obtained at different incineration temperature of the leather waste shavings, (a) Incineration temperature $=850^{\circ} \mathrm{C}$; (b) Incineration temperature $=950^{\circ} \mathrm{C}$, (c) Incineration temperature $=1050^{\circ} \mathrm{C} ;(\mathrm{d})$ Incineration temperature $=1150^{\circ} \mathrm{C}$

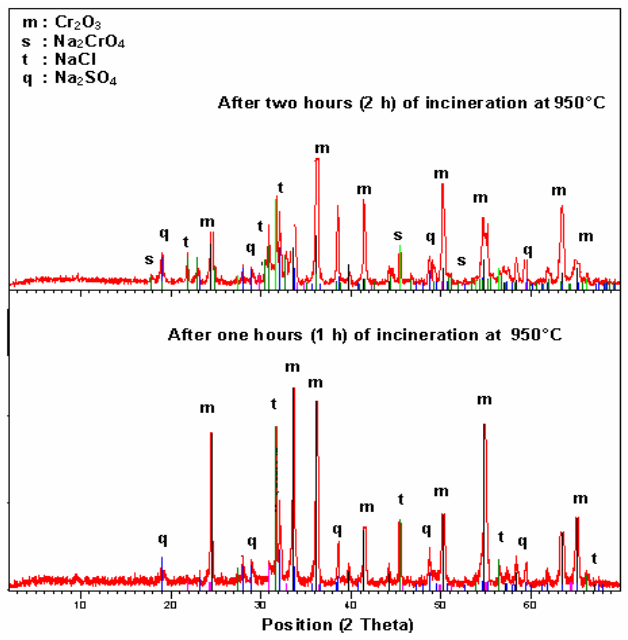

Fig. 3: XRD patterns of the bottom ash obtained after 1 and $2 \mathrm{hrs}$ of incineration at $950^{\circ} \mathrm{C}$ from the leather waste shavings from the leather waste shavings, sequential extraction procedures were utilized. The scheme of Tessier is applied for samples of sediments or grounds ${ }^{[16]}$. However many authors applied the diagram of Tessier with some minor modifications on the residues of incineration of municipal waste as the bottom ash ${ }^{[17]}$.

The scheme is displayed in Table 3. $\mathrm{Cr}$ was partitioned into exchangeable, carbonate-bound, Oxides-bound, organic-bound and residual fraction. Results are shown in Table 4.

Chromium repartition is nearly equitable between the exchangeable form, carbonate bound, oxides bound and organic bound. These results indicate clearly that the chromium in the bottom ash does exist as multi forms.

\section{CONCLUSION}

Incineration tests of the leather waste shavings show that $1100^{\circ} \mathrm{C}$ is the most efficient temperature for 
incineration to reduce chromium content in the atmosphere and that $85 \%$ of the chromium in the leather waste shavings can be found in the bottom ash. The morphology and the composition of the bottom ashes obtained by incineration at different temperature from the leather waste shavings was examined by different technique and the results gotten watch that Chromium repartition in the bouttom ashes is nearly equitable between the exchangeable form, carbonate bound, oxides bound and organic bound. A part of trivament of trivalent chromium $\left(\mathrm{Cr}^{+3}\right)$ changes in hexavalent chrome $\left(\mathrm{Cr}^{+6}\right)$ under shape of $\mathrm{Na}_{2} \mathrm{CrO}_{4}$ when one increases the time of incineration.

\section{REFERENCES}

1. Okamura, H. and K. Shirai, 1976. Treatment of tanning waste by air oxydation. J. Am. Leather Chem. Assoc. 71: 173-179.

2. Cot, J. and E. Gratacos, 1976. Elimination of leather waste by incineration AQEIC Bol. Tec., 26: 353-376.

3. Jones, B.H., 1978. Incineration of leather waste U.S. Patent, 4: 86, 319.

4. Ioan, F.and D. Filofteia, 1978 Rom. Patent, 65: 477.

5. Okamura, H., N. Tanaka and K. Yashura, 1981. Hikaka Kagaku, 27: 83-88.

6. Yatribi, A., A. Nejmeddine and L. Boukhars, 2001. Contribution a la valorisation industrielle des dechets de tanneries : cas de la tannerie. Annales de chimie Science des materiaux, 26 : 107-112.

7. Eddings, E.G. and J.S. Lighty, 1992. Fundamental studies of metal behavior during dolids incineration. Combust. Sci. Technol., 85: 375-485.

8. Ebbinghaus, B.B., 1992. Analysis of chromium volatility in the DWTF incinerator and in the molten salt processor. Proc. Incineration Conf., pp: 599-604, Albuquerque, NM.
9. Jyh-Cherng, C., M.-Y. Wey, B.-C. Chiang and S.M. Hsieh, 1998. The simulation of hexavalent chromium formation under various incineration conditions. Chemospher,. 36: 1553-1564.

10. Yoshiaki, M., M. Kazuhiro, K. Shigero, Y. Satoshi, U. Shunichiro, Junya and K. Nobuhiko, 2006. Leaching behavior of heat treated waste ash. Fuel, 85: 401-409.

11. Chuan, M.C. and J.C. Liu, 1996. Release behavior of chromium from tannery sludge. Wat. Res., 30: 932-938.

12. Oliver, J.W., W.C. Kreye and P.H.H. King, 1975. Water Pollut. Control Fed., 47: 2490-2497.

13. Bartlett, R.J. and J.M. Kimble, 1976. Behaviour of chromium in soils: I. Trivalent forms. J. Environ. Qual., 5: 379-386.

14. Taylor, M.M., E.J. Diefendorf, J.G. Phillips, S.H. Feairheller and D.G. Bailey, 1986. J.Am. Leather Chemists Assoc., 81: 4-18

15. Chandler, A.J., T.T. Eighmy, J. Hartlèn, O. Hjelmer, D.S. Kosson, S.E. Sawell, H.A. Van der Sloot and J. Viehlow, 1997. Municipal solid waste incinerator residues. Amsterdan, Elsevier, pp: 974.

16. Tessier, A., P.G.C. Campbell and M. Bisson, 1979. Sequential extraction procedures for the speciation of particulate trace metals. Anal. Chem., 51: 844851 .

17. Stegemann, J.A and J. Schneider, 1991. Leaching potential of minicipal waste incineration bottom ash as a function of particle size distribution. In Waste Materials in Construction (Ed. Goumans J.J.J.R., Van der sloot H.A. and Aalbers Th.g.), Elsevier, pp: 135-143. 